\title{
The first oases in Eastern Arabia: society and craft technology, in the 3rd millennium BC at Hili, United Arab Emirates
}

Les premières oasis en Arabie orientale: sociétés et techniques artisanales au III millénaire av. J.-C. à Hili, Émirats arabes unis

\section{Sophie Méry}

\section{(2) OpenEdition}

\section{Journals}

Electronic version

URL: http://journals.openedition.org/ethnoecologie/1631

DOI: 10.4000/ethnoecologie.1631

ISSN: 2267-2419

\section{Publisher}

Laboratoire Eco-anthropologie et Ethnobiologie

\section{Electronic reference}

Sophie Méry, «The first oases in Eastern Arabia: society and craft technology, in the 3rd millennium BC at Hili, United Arab Emirates », Revue d'ethnoécologie [Online], 4 | 2013, Online since 05 July 2016 connection on 19 April 2019. URL : http://journals.openedition.org/ethnoecologie/1631 ; DOI : 10.4000/ethnoecologie.1631

This text was automatically generated on 19 April 2019

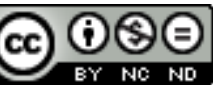

Revue d'ethnoécologie est mis à disposition selon les termes de la licence Creative Commons Attribution - Pas d'Utilisation Commerciale - Pas de Modification 4.0 International. 


\section{The first oases in Eastern Arabia: society and craft technology, in the 3rd millennium BC at Hili, United Arab Emirates}

Les premières oasis en Arabie orientale : sociétés et techniques artisanales au III millénaire av. J.-C. à Hili, Émirats arabes unis

\section{Sophie Méry}

\section{Introduction}

1 Quite different from the models known for the Near and Middle East, the Neolithic in eastern Arabia (7th-4th millennia BC) is characterised by the absence of agriculture. About 7000-6500 cal BC, animal husbandry appeared, and on most ca. 5500-3200 BC Neolithic sites along the coasts of the United Arab Emirates (U.A.E.) and the Sultanate of Oman, goats, sheep, cattle, and dogs appeared in their domesticated form. In contrast, agriculture did not become established until 4000 years later with the beginning of the Bronze Age (Beech \& Sheperd 2001). Copper metallurgy generally preceded the appearance of local pottery, not in evidence until the beginning of the $3^{\text {rd }}$ millennium $B C$, at the beginning of the early Bronze Age (EBA).

2 The process of neolithisation occurred in the Oman peninsula and in Yemen between ca. 6500 and $5000 \mathrm{cal} \mathrm{BC}$. The domestication of caprids and cattle (Uerpmann et al. 2000, Martin et al. 2009), possible seasonal or even permanent sedentarisation, and the establishment of populations in large villages on the coast provide evidence for this, as do pressure technique in lithic production and the fluting process (Biagi \& Nisbet 2006; Charpentier 2008; Munoz et al. 2013). It is also at this time that new currents of circulation were created in Arabia. For example, contacts were gradually established between the 
populations along the shores of the Persian Gulf, which channelled Ubaid pottery from lower Mesopotamia starting in the middle of the 6th millennium and up to the end of the 5th millennium. These currents of circulation were to increase in the 5th millennium, attested by various objects and materials, especially natural products such as marine shells, obsidian and soft stone, and artificial products such as bitumen and pottery.

Aridification occurred in the Oman peninsula between 4500-4000 BC, causing profound transformations and leading to the formation of societies organised differently. This was the end of the Neolithic. In the 3rd millennium, technologies such as pottery from north of the Strait of Hormuz appeared. The first third of the $3^{\text {rd }}$ millennium is known as the Hafit period, followed by the early Bronze Age known as the Umm an-Nar period that lasted until $2000 \mathrm{BC}$.

\section{The emergence of the first oases}

\section{Subsistence economy and way of life}

4 The early Bronze Age corresponds to the establishment of agricultural oases and villages (Figure 1) (Al-Jahwari 2009). From then on some occupations/sites were at least partly sedentary, located in contact with the water tables of the foothills and in the valleys. Hili (Figures 2 and 3), $150 \mathrm{~km}$ east of Abu Dhabi, remains at present, more than 30 years after its excavation, the best documented agricultural oasis recorded for this period. This oasis settlement based on the cultivation of date palm, various cereals, legumes and fruits, was in activity beginning in the $3^{\text {rd }}$ millennium BC (Cleuziou \& Costantini 1980; Tengberg 2003). The dating of the period I level of Hili 8 has been questioned by D. Potts (1986, 1998:46) on the basis of typological parallels with the few sherds of Mesopotamian pottery found at the site and on his criticism of the radiocarbon dates. Although these arguments are not without value, a new element can be brought to the debate. A study of the stones integrated into the domestic architecture at Hili 8 showed that building II, dated to the very beginning of period II at Hili 8 (architectural phase IIa, Cleuziou 1989: 68) includes stones from the facing of three Umm an-Nar tombs. These tombs do not date to the beginning of the architectural sequence of the necropolis of Hili, which dates entirely to the Umm an-Nar period (phase 1), but to the following phase (phase 2). This means that either the period I of Hili 8 dates entirely or partly to the Umm an-Nar period, or that the beginning of the Umm an-Nar period is not represented in the new excavations of Hili 8 and that period I is to be ascribed to the Hafit period. Only new datings on the materials of period I or new excavations can usefully restart the debate. However, and this is a very important discovery, it is to be noted that a mud brick tower at Bat excavated in the 2000s by an American team produced decorated sherds of Mesopotamian pottery dating from the Jemdet Nasr period to the Early Dynastic I-II periods (Possehl et al. 2010). At Ra's al Hadd (Ja'alan, Sultanate of Oman), the coastal site of HD-6 produced domesticated plants remains, but it is unclear if these were local or cultivated inland. 
Figure 1. Map of the main Early Bronze Age oases and coastal settlements in the Oman peninsula

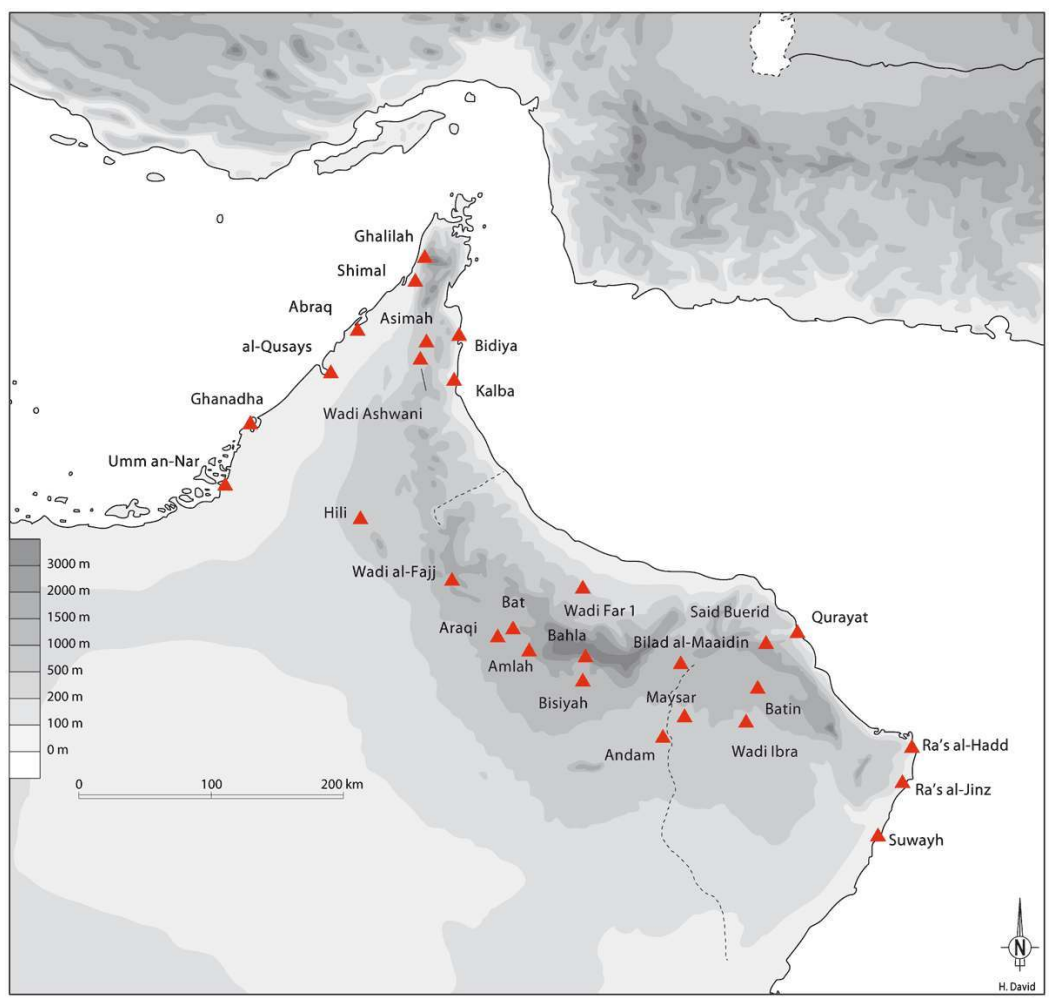

Drawing H. David/Mission archéologique française aux E.A.U.

Fig. 2. The mudbrick towers of the Hili 8 settlement

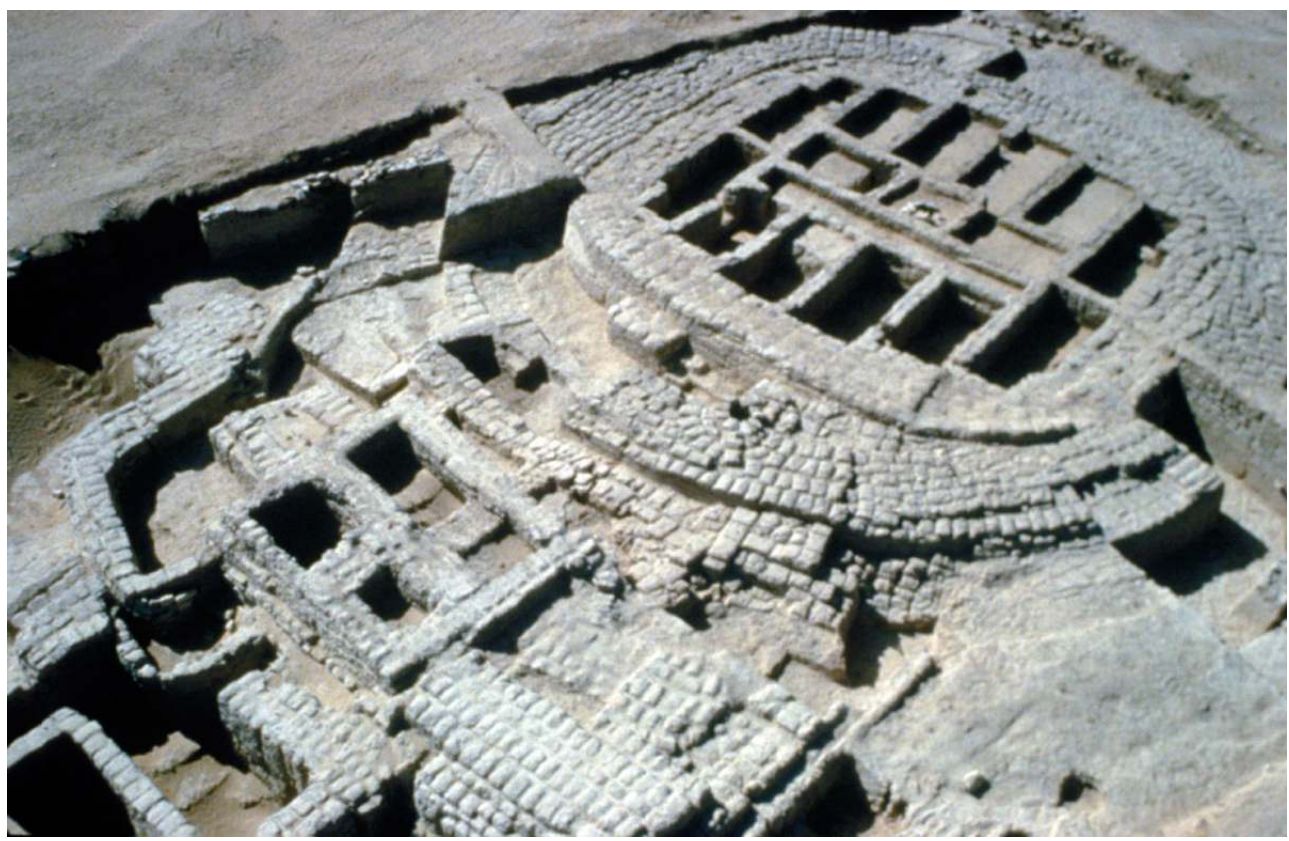

First construction at beginning of the 3rd mill. cal BC or the Hafit period. Two re-constructions were done during the second part of the 3rd mill. cal BC or the Umm an-Nar Period

Photo S. Cleuziou/Mission archéologique française à Abou Dhabi 
Fig. 3. Hili and the region of Al Ain. Main sites of the Bronze Age

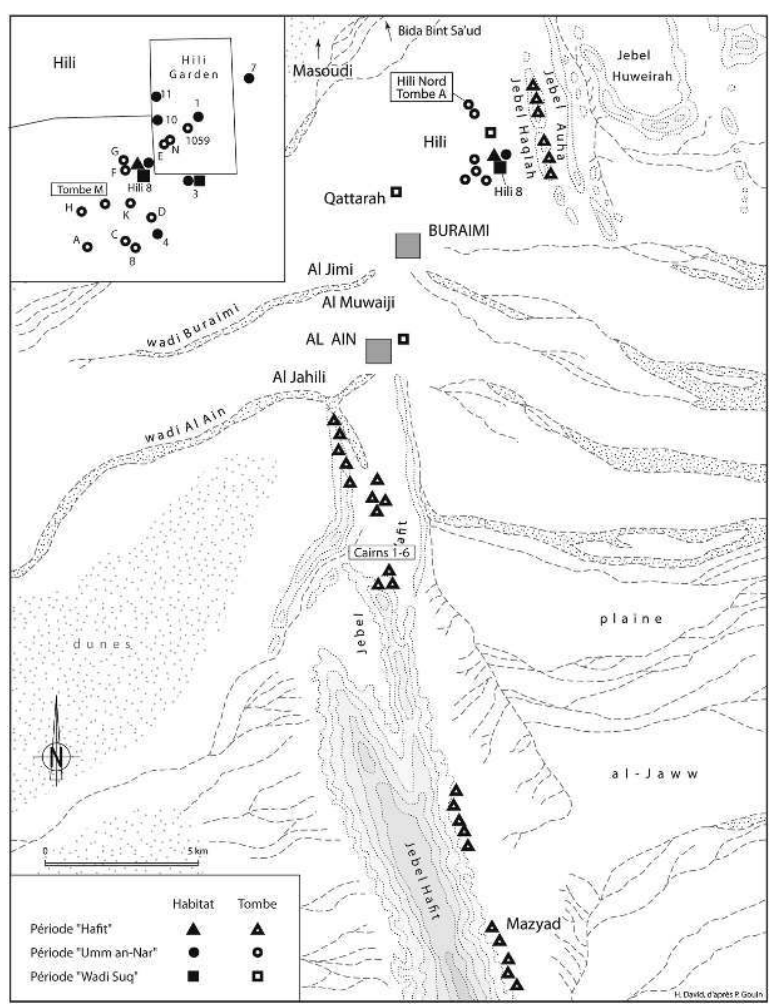

(c) H. David/Mission archéologique française aux E.A.U.

Evidence of agriculture was also recovered at earlier but still early Bronze Age (EBA) sites such as Bat, Maysar 1, Tell Abraq and Umm an-Nar (Cleuziou \& Tosi 2000, Costantini \& Audisio 2000, Frifelt 2002, Potts 2000, Weisgerber 1981, Willcox 1995, etc). In a climate that was as arid as it is today, methods of irrigation were necessary, of which certain elements, such as canals and wells, are in evidence, for example at Hili (Figure 4) or Maysar (Weisgerber 1981). This system is however not that of the falaj, networks of underground water conveyance that probably did not appear until the Iron Age. Unlike the situation on coastal sites such as Umm an-Nar and Ra's al-Jinz, domestic animals, particularly cattle, strongly contributed to the subsistence economy, at both Hili and Maysar, two sites in the interior of the Oman peninsula (Uerpmann \& Uerpmann 2008). Gazelle and wild dromedary were hunted, but the part played by hunting was not important. The donkey was domesticated and cattle were used for carrying loads and for the transport of goods. 
Fig. 4. Small water canals at Hili 8.

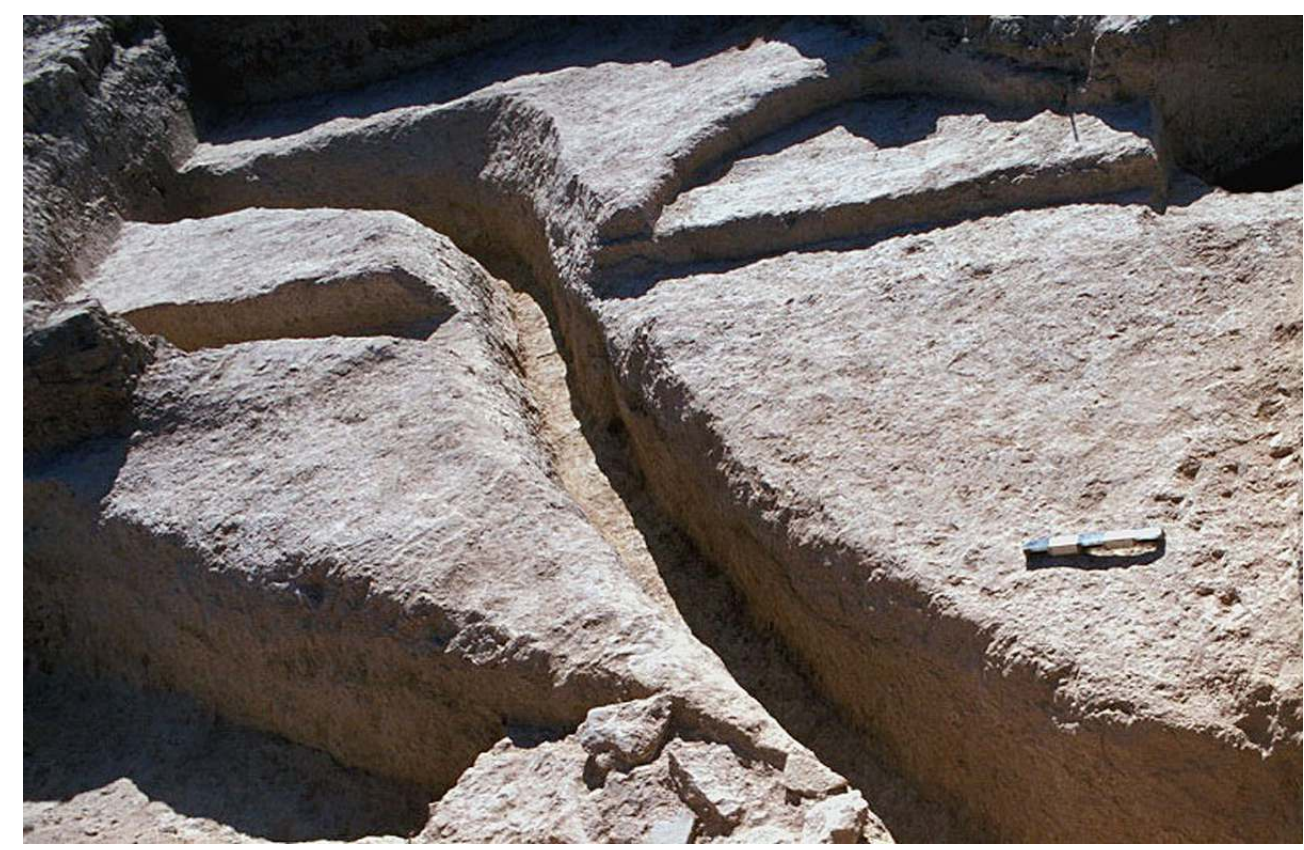

(C) S. Cleuziou/Mission archéologique française à Abou Dhabi

\section{The craft of pottery}

6 The EBA villages of the interior, where the oases were located, were organised around towers, which may be rather safely interpreted as affirmations of power. In these villages, excavation by several local and foreign teams has not only brought to light the existence of an agricultural population, but also that of specialised craftsmen. There were stonecutters, metallurgists, potters, makers of crockery in soft stone and lapidaries.

In the EBA, with the creation of oases, an occupation of geographic zones that had been little exploited or not at all was to develop in the Oman peninsula. This way of life favoured the exploitation of new mineral resources and the appearance of specialised crafts. The period corresponds to fundamental changes in the local system of technology and to the transfer from the Indo-Iranian regions of pyro-technologies, which produced pottery and copper alloys. In the case of pottery, this transfer meant that potters travelled from north of the Strait of Hormuz, in particular from Pakistani Makran to the Oman peninsula.

8 From then on craft tradition was to develop in an autonomous manner. The oldest pottery of local fabrication was identified on the site of Hili 8 (Méry 2000). These types of pottery date to the very beginning of the 3rd millennium according to the chronology of S. Cleuziou (1989).

9 From the time of its appearance on the site, fine red pottery painted in black on red slip was evidence of high technical knowledge : the paste is very fine (few inclusions over 50 $\mu \mathrm{m}$, very rare over 100-150 $\mu \mathrm{m}$ ), the techniques of shaping (coils shaped on a rotating device) and of firing (oxydizing atmosphere predominant) were well mastered (Figure 5). However distinct, this local tradition is related to the ceramic traditions of the plain of Dasht, in Pakistani Makran, in the shapes and the decoration of the vessels but especially 
by certain characteristic technical features. However we can differentiate the two groups, on the colour range of the pasteware, granulometry, etc. The differences are small but visible macroscopically: the composition of the paste of the two groups, UAE/Oman and Dasht, is distinct (Méry \& Blackman 2005). As early as 2600-2500 BC (but probably even before) and until 2100-2000 cal BC, some vessels made in the plain of Dasht, in fine gray or red pottery, were brought to the Oman peninsula (Méry et al. 2012).

Fig. 5. Fine red Omani pottery, typical of the 3rd millennium BC local production

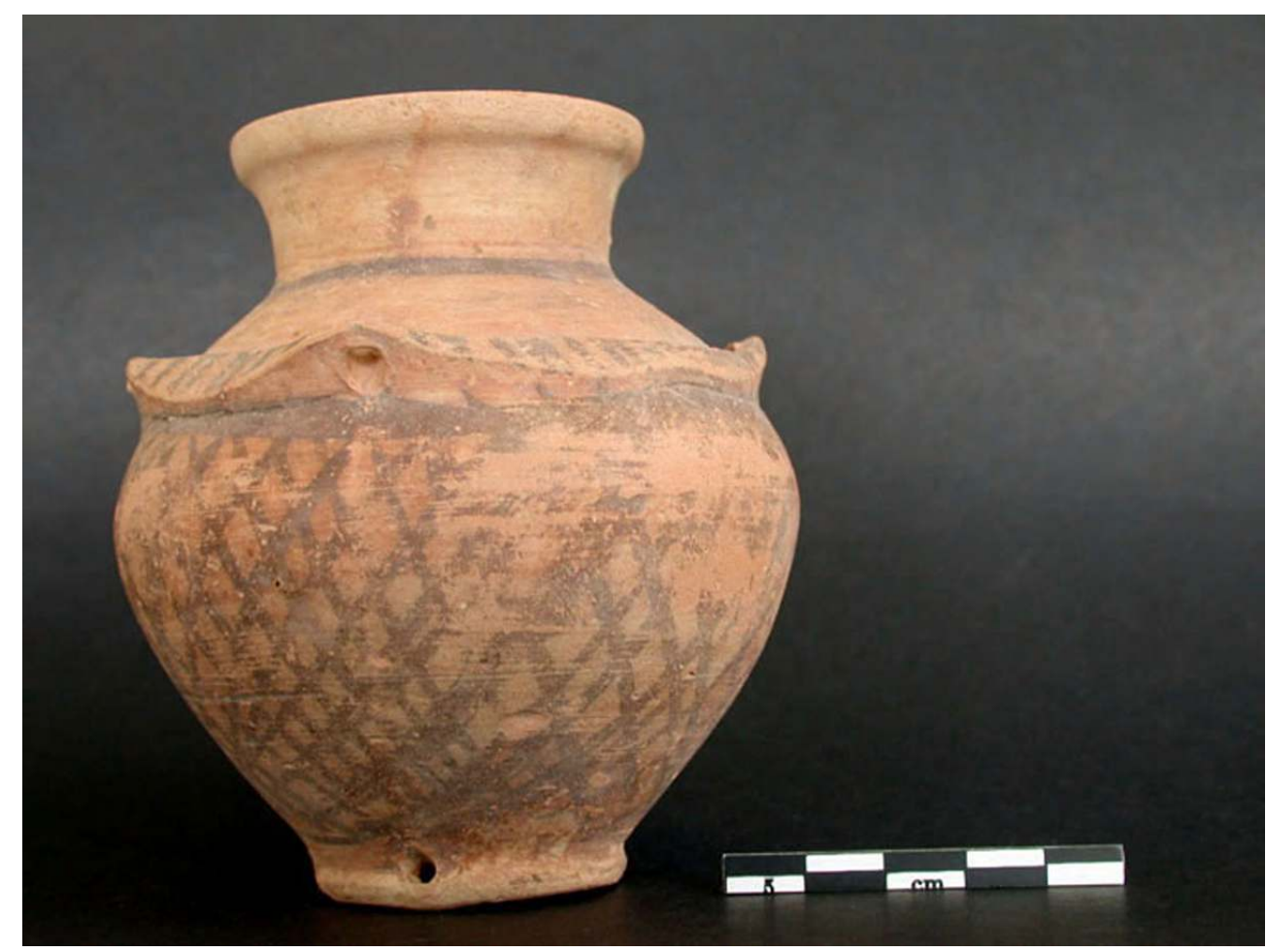

(c) S. Méry/Mission archéologique française aux E.A.U.

The local production of domestic pottery, with sandy paste and geometric decoration painted in black on a red slip, was to develop beginning in $2500 \mathrm{BC}$ in the foothills of the Oman mountains, on sites such as Hili (Figure 6), Bat, Amlah and Maysar, but also on the Indian Ocean coast, on the site of Kalba. Regionalisation of the style of the different groups of production thus began (Méry 2000). At Hili, the use of rotation to shape domestic pottery is certain of around $2500 \mathrm{BC}$, but wheel-turned pottery, that is, from a central ball, hollowed and raised, was probably not yet mastered to make a complete vessel. It is not even certain that the latter technique was used at the end of the $3 \mathrm{rd}$ millennium $\mathrm{BC}$, as the recent experimental study of the material from tomb $\mathrm{N}$ at Hili, dated to 2200-2000 BC, has shown (Méry et al. 2010). In fact, we discovered that most of the domestic vessels at Hili were fabricated using the coil method and finished on a rotating device, or shaped with coils or on a 'tournette' or turned on a 'potter's wheel', on a modelled pancake form or on a wheel turned base. 
Fig. 6. Domestic pottery from tomb $\mathrm{N}$ at Hili garden and Tomb A at Hili North

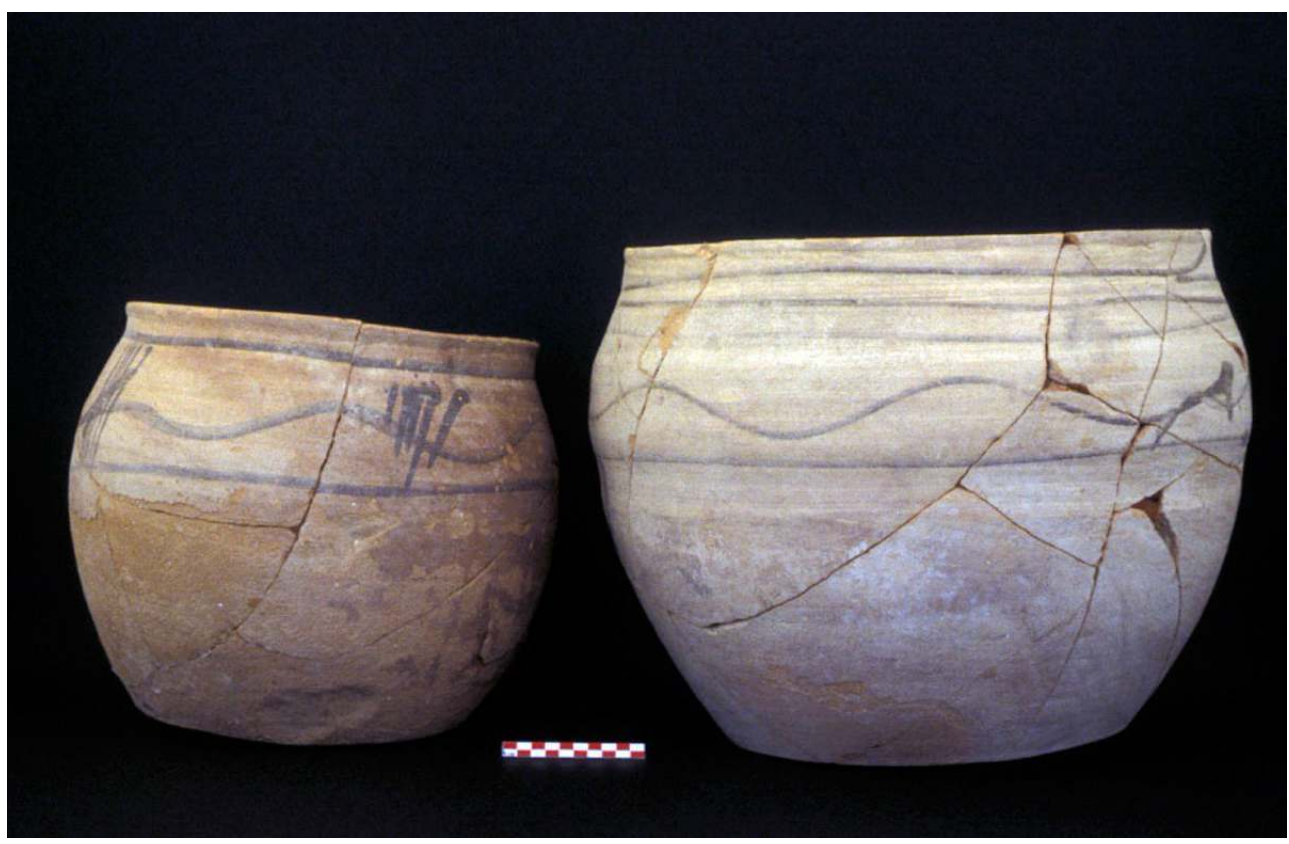

(c) S. Méry/Mission archéologique française aux E.A.U.

11 The technical skills required and the variety of products found indicate that production was organised around dwellings rather than specialised workshops. The potters were 'specialists' in that they were masters of their techniques, which were not shared by everyone. But it is likely that they were not full-time specialists but farmers as well (on the question of the specialization in the Oman Peninsula see also Weeks 2003, Rouse and Weeks 2011).

12 In the middle Bronze Age, after $2000 \mathrm{BC}$, a certain number of elements indicate a/some restructuration of the pottery production. At Hili and Shimal (Emirate of Ra's al Khamaih, near the Straits of Hormuz) funerary pottery and domestic pottery were henceforth fabricated in the same production units (Méry 2000), because the pastewares are very close or similar except the granulometry of the coarse or semi-coarse mineral fraction. Compared to the EBA, there was a growing use of pottery and a wider diversification of the types of vessels employed, which would have had a repercussion on the modes of production. The probability of development of itinerant specialists is rather high if we consider the stylistical homogeneity of the Wadi Suq pottery from the northern Emirates to the Ja'alan in the Sultanate of Oman. By style, we mean all technical features of the vessels plus their morphological, morphometrical, and decorative traits.

\section{Necropolises and stone cutters}

13 It was at the end of the 4 th millennium $\mathrm{BC}$ that a new type of tomb became widespread in the Oman peninsula, called 'Hafit' after the eponymous site (Frifelt 1971). These are collective tombs in which the number of buried individuals could reach about thirty (Benton and Potts 1994, Santini 1987, Munoz 2004), probably members of one 'family' (genetically related or by alliance). The monuments, in dry stone, without foundations and of truncated cone shape, contained only one burial chamber. Grouped together in 
sometimes very vast necropolises, and located on rocky outcrops which render them visible from afar, Hafit tombs are - like traditionally by protohistorians in Western Europe Protohistory - considered to be territorial markers. It was proposed that they were indicative of tribal unity by Cleuziou (2002), and the present author supports this hypothesis (also retained by Giraud 2007) as well as the probable ancient origin of the eastern arabian tribal system in the Neolithic.

The discovery of oasis settlements of the so-called Hafit period, i.e. the first phase of the EBA (3200/3100-2700/2600 cal BC) remains difficult, only the sites of Hili 8 (Cleuziou 1989) and Bat (tower 1147 of Matariya, cf. Possehl et al. 2010: 19) have produced clear remains of domestic occupation with, for example, typical pottery from Lower Mesopotamia dated to the first third of the 3rd millennium BC. The complex coastal settlement of Ra's al-Hadd HD-6 (Azzara 2009) was also occupied in this period but no Mesopotamian pottery has so far been found on the site.

Beginning in the second third of the 3rd millennium BC, the settlements are better known, and the necropolises are constructed nearby or even within the villages. The funerary structures in use in the Umm an-Nar period are of three main types: monumental circular tombs, pit-graves and 'ossuaries' (Méry 2010).

The monumental circular tombs that in elevation appear as truncated half-spheres (Bessac \& Dubeuf, forthcoming) are the most frequently identified funerary structures. There were several tens of individuals buried per monument in the first part of the Umm an-Nar period (as in Cairn V at the Umm an-Nar site or Tomb M at Hili Garden), which reached several hundred at the end of this period as at Tomb A at Hili North, Tell Abraq and Tombs UNAR 1 and 2 at Shimal (Bondioli et al. 1998; Potts 2000; Carter 2002; Cleuziou et al. 2011), the burials appearing for the most part to be of individuals who died naturally (McSweeney et al. 2010). The stratigraphy of the funerary deposits, of which the study has not always been favoured by the archaeologists, was often disturbed by looting, and radiocarbon dating remains rare, which complicates or even makes impossible a reliable estimation of the duration of use of the tombs. But the recent study of the necropolis of Hili indicates that this duration was less than two centuries - even though there are cases of re-occupations, according to ${ }^{14} \mathrm{C}$ dates and artefactual evidence (McSweeney et al. 2008). This is most probably also the case of the Tomb of Tell Abraq, and UNAR 1 and 2 at Shimal, even though still difficult to prove, due to the difficulty to accurate ${ }^{14} \mathrm{C}$ datation when collagene is missing and only the mineral fraction (apatite) can be dated (Munoz et al. 2013).

The compartmented plan and the dimensions of the monumental circular tombs varied during the course of the Umm an-Nar period, the interior space always being separated in two chambers with independent entrances opposite each other. They were covered with large stone slabs and the external face made of bush-hammered stones. At the end of the $3^{\text {rd }}$ millennium, some of them included an underground level while others reached $14 \mathrm{~m}$ in diameter. The numerous funerary offerings, which included both pottery and stone vessels, metal objects and ornaments, varied over time, according to the development of trade with Mesopotamia, with the region that includes south-western Iran and Pakistani Makran, and with the Indus civilisation - especially the southern part of the Indus hydrographic basin i.e. the Indus river valley (Méry 2000, Cleuziou \& Méry 2002).

At Hili Garden and Hili North necropolises, a study of construction techniques of the monumental (or, exceptionally, cyclopean) circular tombs has enabled determination of 
the relative chronology of the monuments (Gagnaison et al. 2004, Gagnaison 2006). This was confirmed by later work, carried out as a blind test (Bessac \& Dubeuf forthcoming). A progressive development of techniques and investment in construction has been recorded for a period of about six or seven centuries, and three successive groups could be distinguished according to whether the structures and their elements were of simple, intermediate, or elaborated fabrication. The distribution of tombs of different phases does not follow any particular organisation in the necropolises of Hili and the time intervals between constructions are not known. The tombs would have been constructed one after another or in groups of two at the maximum (such as tombs $F$ and $G$ ), although the use of some could have overlapped, and some could have occasionally been reused.

19 For the tombs of simple fabrication (Phase 1, the earliest in the Hili architectural sequence of the monumental tombs) (Figure 7), the stones of the facing, worked perpendicular to their natural layering, are small, and the work of bush-hammering on the facing is unequal; this work with small building stones could have been that of occasional stonemasons and concerns four or five tombs of the necropolis (tombs Z, F, G, $\mathrm{H}$ and perhaps $\mathrm{D}$ ). In the tombs of elaborated fabrication (Phase 3, the latest in the necropolis) (Figure 8), the facing stones are set upright with their strata in a vertical position, as the stonecutter would thus not have been limited for the heights of the courses to the width of the natural layers. The blocks can measure up to $2.55 \mathrm{~m}$ long (tomb 1059 at Hili Garden, south gate). There are four known tombs built with these great blocks (tombs A and B at Hili Garden, tombs A and B at Hili North), one tomb being of cyclopean masonry, that is, made of at least two courses of blocks larger than the size of a human (tomb 1059 at Hili Garden). To give an idea of the weight that had to be transported, the block of the south gate of tomb 1059 was evaluated at 2,125 tons. The latest tombs are characterised by perfect joins in the facing, stepped in order to ensure the best stability for the building. The other tombs of the necropolis of Hili Garden are of intermediate fabrication and chronology (tombs C, J, M, E). 
Fig. 7. Tomb $\mathrm{H}$ at Hili Garden. Early phase of the Hili necropolis

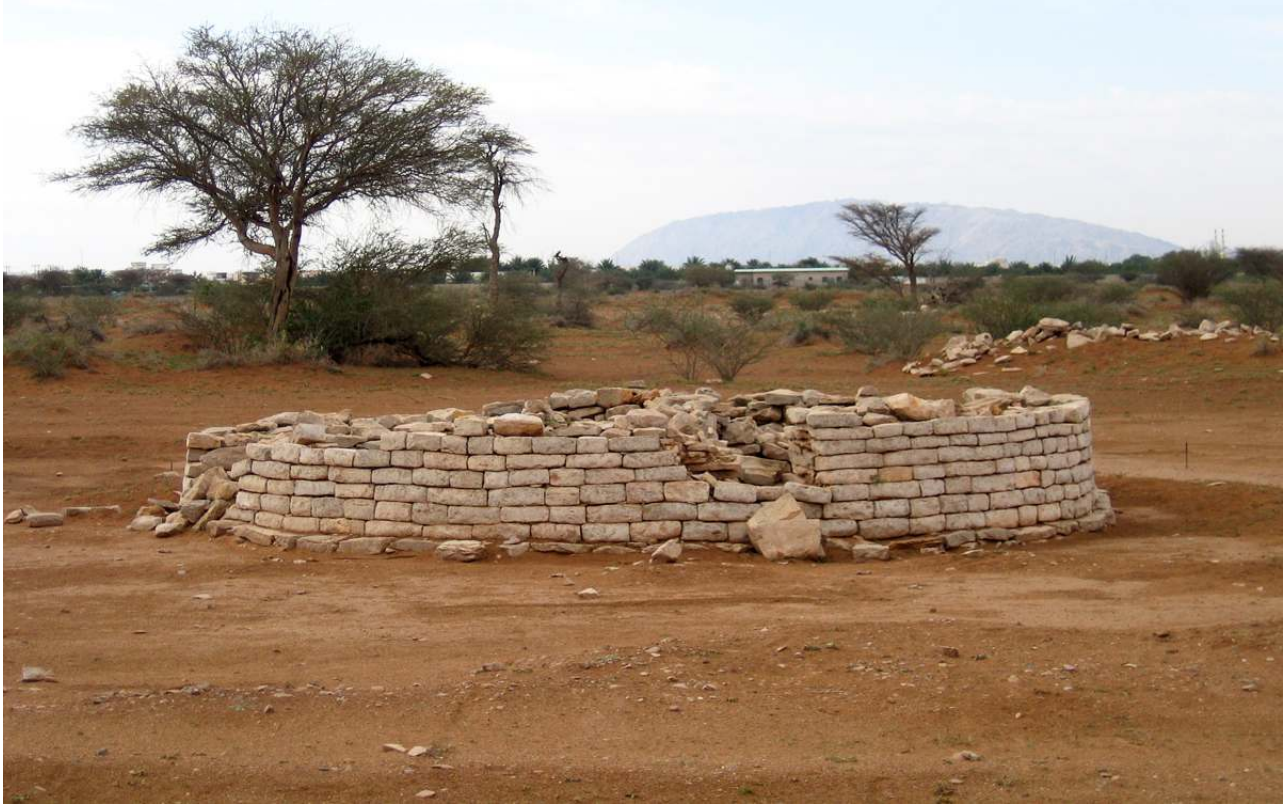

(C) P. Dubeuf/Mission archéologique française aux E.A.U.

Fig. 8. Tomb 1059 at Hili Garden. Early phase of the Hili necropolis

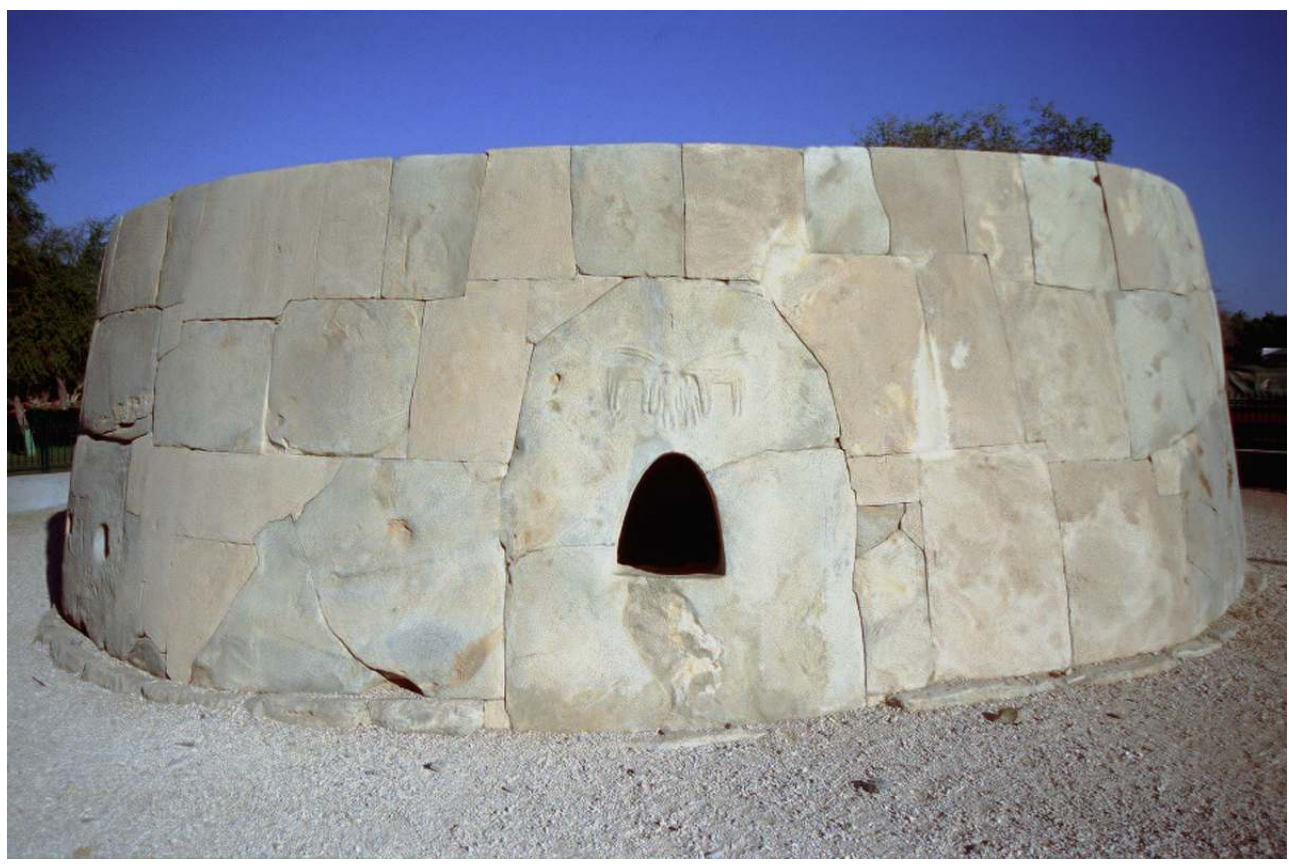

(c) C. Gagnaison/Mission archéologique française aux E.A.U.

21 From this study, it may also be seen that the funerary architecture of the Umm an-Nar period was the fruit of a local craft production, structured and specialised. The degree of task specialisation developed gradually up to $2100 \mathrm{BC}$, and this process was recorded in 
detail in the necropolis of Hili by a team of the French archaeological mission to the U.A.E. Beginning in the second third of the 3rd millennium BC, the working of architectural stone became specialists' work at Hili, in the sense of work not carried out by everyone; then, during the last third of the 3rd millennium, it became the work of specialists with a high and even very high level of competence.

There were in the Umm an-Nar period two other types of grave structures which are different in nature, size and manner of functioning from the monumental circular tombs, although dug nearby. They are not frequently known to date, but this is due to their subterranean nature that makes them more difficult to spot.

The first type corresponds to graves filled with bones mixed with pottery and objects. These are secondary burials rather than the results of emptying graves.

The second type consists of large collective graves that date to the end of the $3^{\text {rd }}$ millennium, situated in immediate proximity to the earlier monumental circular tombs. They heralded the big or huge underground tombs of 'Wadi Suq' type from the Middle Bronze Age, when, at about $2000 \mathrm{BC}$, a new culture was to become widespread in the whole of the Oman peninsula, and in many aspects the material culture was to change.

\section{Trade in the Early Bronze Age}

The first long-distance trade was established during the Neolithic in the southern part of the Gulf, and intensified and diversified in the Bronze Age. Limited to lower Mesopotamia and the north of the Gulf in the 6th-5th millennia, it was to include the regions situated north of the Strait of Hormuz in the 4th and 3rd millennia (Cleuziou \& Méry 2002). The emergence and development of these trade networks certainly favoured the appearance of specialised craftsmen, and thus more stratified societies. The contacts that existed with Mesopotamia, indirect in the 6th-5th millennia, were probably no longer so in the 3rd millennium, once the region was well integrated into the networks that crossed the Near East and means of transport enabled the establishment of direct contacts. Contacts appear to have become denser in the early Bronze Age, and organised in different ways.

For the Bronze Age, it is known that many goods were traded: coastal products such as shells, products from the interior of Oman such as copper, vessels in soft stone or pottery, and foreign merchandise such as the pottery, ivory and elements of stone ornaments recovered in the excavations. Cuneiform texts are another source of information that we have for reconstructing the history of trade. They show that there was a state of intense commerce in the Gulf in the 3rd millennium, including especially the land of Dilmun (from Kuwait to Qatar), Meluha (which corresponds to the Indus civilisation) and Magan (the United Arab Emirates and the Sultanate of Oman). Magan was most probably the main or one of the main suppliers of copper for Mesopotamia, and it was exported by sea in the form of ingots and manufactured objects. Other goods from this region were exported to Mesopotamia. These were mainly raw rocks such as diorite, intended for statuary and architectural decoration, as well as agricultural products such as palm stems, dates and animals (goats). In return, the Mesopotamians sent cereals, fabrics and skins.

After $2500 \mathrm{BC}$, many foreign products discovered in the Oman peninsula came from the Indus civilisation: terra cotta vessels (Figure 9), especially jars serving to transport 
foodstuffs, and luxury objects such as ivory combs, cornelian beads engraved with acid (Figure 10) and cubic weights in flint.

28 This long-distance trade should not, however, overshadow the importance of the local and regional trade which was the basis for trade within the Oman peninsula and constituted in this region a fundamental factor for the cultural homogenisation that began in the Neolithic.

Fig. 9. Decorated pottery from the Indus valley, found in tomb $\mathrm{N}$ of Hili

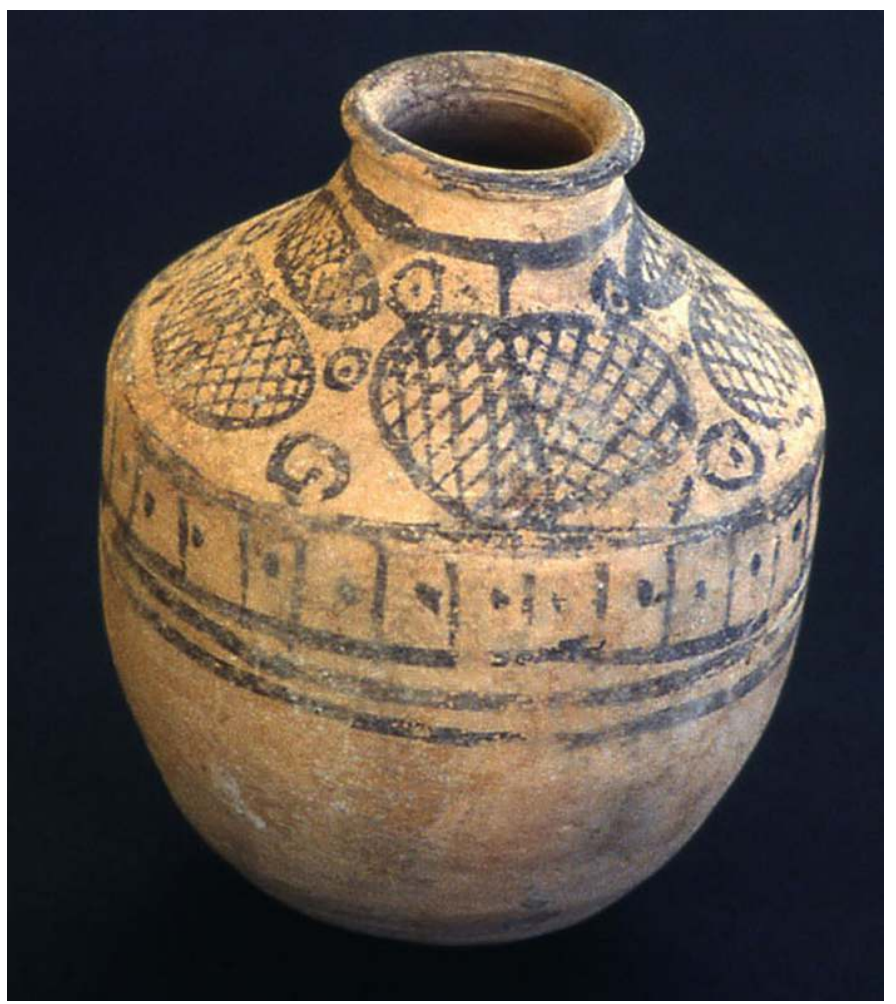

(c) S. Méry/Mission archéologique française aux E.A.U. 


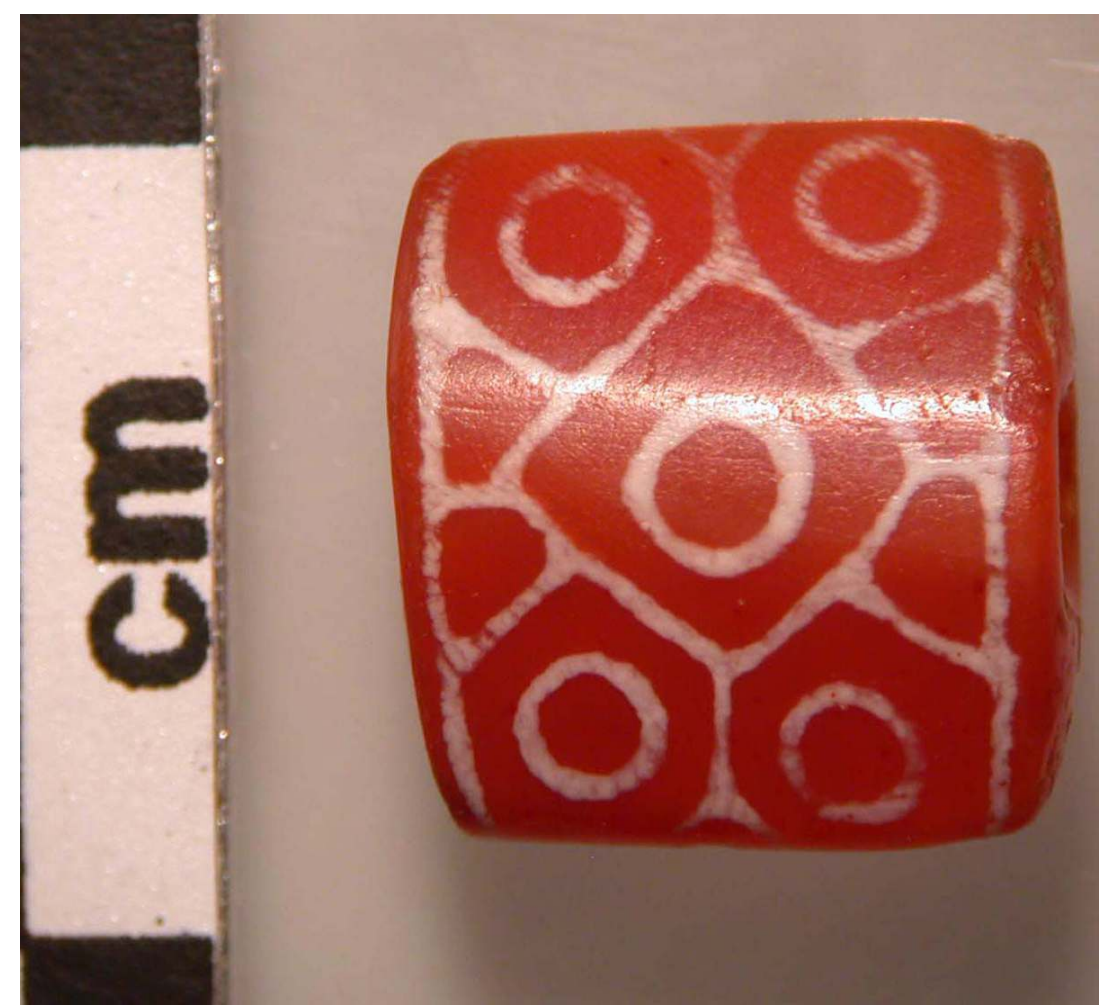

(c) O. Brunet/Mission archéologique française aux E.A.U.

\section{Conclusion}

The societies of the Oman peninsula evolved during early proto-history in the direction of greater complexity and more advanced integration. The model changed from one in which goods circulated in a traditional manner of distribution between communities to a system in which certain goods were specific products filling demands that were exterior or mainly exterior to those of the producer population. At the same time, crafts diversified, seen in particular in the appearance of elaborated architectural stone and the development of pottery. Artisans who were clearly specialised appeared, possessing a level of technological expertise that was greater than before. They probably devoted periods of time that were longer and more regular to the production of objects.

The local societies changed from village or 'clan' groups with no leader to simple chiefdoms (in reference to the typology of Johnson and Earle, 1987) or societies of tribal type (after Cleuziou 2002, Cleuziou and Tosi 2007). The distinction is not clear however, as the tribe is defined first of all by ethnicity (which is possible to determine in our case), while the chiefdom is above all a political unit (but unambigous archaeological remains of such an organisation are still to be found in our case). No attempt at modelling to differentiate tribe and chiefdom in relation to their size has yet been initiated, either in Arabia or the Near East, and work on defining territories has only just begun in the Oman peninsula for the Bronze Age, through spatial analysis (Giraud 2007). In any case, the construction of towers 20 meters in diameter and monumental tombs are evidence that collective activities were coordinated in the $3^{\text {rd }}$ millennium for the benefit of the entire 
community, an indication that those who represented authority had a power of "constraint" on the members of the group. These two types of building are thus related to authority, and in this sense to a political unit of the chiefdom type.

\section{BIBLIOGRAPHY}

Al-Jahwari N. S. 2009 - The agricultural basis of Umm an-Nar society in the northern Oman peninsula. Arabian Archaeology and epigraphy 20: 122-133.

Azzara V.M. 2009 - Domestic architecture at the Early Bronze Age sites HD-6 and RJ-2 (Ja'alan, Sultanate of Oman). Proceedings of the Seminar for Arabian Studies 39: 1-16.

Beech M. \& Shepherd E. 2001 - Archaeobotanical evidence for early date consumption on Dalma Island, United Arab Emirates. Antiquity 75, 287: 83-9.

Benton J. N. \& Potts D. T. (Ed.) 1994 - Jabal al-Emalah 1993/4. Report compiled for the Department of Culture and Information, Government of Sharjah, United Arab Emirates, $90 \mathrm{p}$.

Bessac J.-C. \& Dubeuf P. forthcoming - La construction des tombeaux en pierre à Hili. In Méry S. (Ed.) avec des contributions de P. Dubeuf, A. Berthelot, J.-C. Bessac, O. Brunet, A. Dupont-Delaleuf, C. Gagnaison, W.Y. al Tikriti. Les productions artisanales de la fin du $3^{e}$ millénaire à Hili (Al Ain). Travaux de la Mission archéologiques française aux Émirats Arabes Unis, 1998-2006. BAR International Series.

Biagi P. \& Nisbet R. 2006 - The prehistoric fisher-gatherers of the western coast of the Arabian sea: a case of sedentarization? World Archaeology 38(2): 220-238.

Bondioli L., Coppa A. \& Macchiarelli R. 1998 - From the coast to the oasis in Prehistoric Arabia: what the human osteodental remains tell us about the transition from a foraging to the exchange economy? Evidence from Ra's Al Hamra (Oman) and Hili North (U.A.E.). In Tosi M. (Ed.), Proceedings of the XIII congress 8-14 sept. 1996, International Union of Prehistoric and Protohistoric Sciences, vol. 5, A.B.A.C.O., Forli, p. 229-234.

Carter R. 2002 - Preliminary report on Unar 2 and its ceramics. Bulletin of the Society for Arabian Studies: 5-14.

Charpentier V. 2008 - Hunter-gatherers of the "empty quarter of the early Holocene" to the last Neolithic societies: chronology of the late prehistory of south-eastern Arabia (8000-3100 BC). Proceedings of the Seminar for Arabian Studies 38: 93-116.

Cleuziou S. 1989 - The chronology of protohistoric Oman as seen from Hili. In Costa P. M. \& Tosi M. (Ed.), Oman Studies, Serie Orientale Roma LXIII, IsMEO, Rome: 47-78.

Cleuziou S. 2002 - Présence et mise en scène des morts à l'usage des vivants dans les communautés protohistoriques : l'exemple de la Péninsule d'Oman à l'âge du Bronze ancien. In Molinos M. \& Ziffereo A. (Ed.) Primi Popoli d'Europa. Proposte e riflessioni sulle origini della civilta nell'Europa mediterranea, All'Insegna del Giglio, Florence: 17-31.

Cleuziou S. \& Costantini L. 1980 - Premiers éléments sur l'agriculture protohistorique de l'Arabie Orientale. Paléorient $6: 245-251$. 
Cleuziou S. \& Méry S. 2002 - In between the great powers. In Cleuziou S., Tosi M. et Zarins J. (Ed.): Essays on the Late Prehistory of the Arabian Peninsula, Serie Orientale Roma, IIAO, Roma: 273-316.

Cleuziou S. \& Tosi M. 2000 - Ra's al-Jinz and the prehistoric coastal cultures of the Ja'alan. Journal of Oman Studies 11: 19-73

Cleuziou S. \& Tosi M. 2007 - In the shadow of the ancestors: the prehistoric foundations of the early Arabian civilization. Muscat, Ministry of Heritage and Culture, Sultanate of Oman, $334 \mathrm{p}$.

Cleuziou S., Vogt B. \& Méry S. 2011 - Les premières tombes à chambres multiples : la tombe $\mathrm{M}$ de Hil. In Cleuziou S., Méry S. \& Vogt B. Protohistoire de l'oasis d'Al Aïn, travaux de la Mission archéologique française à Abou Dhabi (Émirats arabes unis). Les sépultures de l'âge du bronze. BAR International Series $2227: 41-71$.

Costantini L. \& Audisio P. 2000 - Plant and insect remains from the Bronze Age site of Ra's al-Jinz (RJ-2), Sultanate of Oman. Paléorient 26(1): 143-156.

Frifelt K. 1971 - Excavations in Abu Dhabi (Oman). Art Asiae 33/4: 296-299.

Frifelt K. 2002 - Bat, a centre in $3^{\text {rd }}$ Millennium Oman. In Cleuziou S., Tosi M. \& Zarins J. (Ed.) Essays on the Late Prehistory of the Arabian Peninsula. (Rome, Serie Orientale Roma 93, Istituto italiano per l'Africa e l'Oriente): 101-110.

Gagnaison C. 2006 - Études géoarchéologiques appliquées à l'usage des matériaux lithiques. Nécropoles préhistoriques de la Péninsule arabique (Al Ain, Bat). Le site ibérique de La Alcudia et les carrières de la Dame d'Elche (Espagne). Thèse de doctorat, Université de Paris 1, 326 p.

Gagnaison C., Barrier P., Méry S. \& al Tikriti W.Y. 2004 - Extractions de pierres à l'âge du Bronze à Hili (Émirat d'Abou Dhabi) et architecture funéraire. Revue d'Archéométrie 28 : 97-108.

Giraud J. 2007 - Restitution d'un espace géographique ancien : la province du Ja'alan à l'Âge du Bronze (Sultanat d'Oman). Thèse de Doctorat de l'Université de Paris 1 Panthéon-Sorbonne, 3 vol., 750 p.

Johnson A.W. \& Earle T.K. 1987 - The evolution of human societies: from foraging group to agrarian state. Stanford, Stanford University Press, $440 \mathrm{p}$.

Martin L., Mccorriston J. \& Crassard R. 2009 - Early Arabian pastoralism at Manayzah in Wâdî Sanâ, Hadramawt. Proceedings of the Seminar for Arabian Studies, 39: 271-282.

McSweeney K., Méry S. \& Macchiarelli R. 2008 - Rewriting the end of Early Bronze Age in the United Arab Emirates, through the anthropological and artefactual evaluation of two collective Umm an-Nar graves at Hili (Eastern region of Abu Dhabi). Arabian Archaeology and Epigraphy 18: $1-14$.

McSweeney K., S. Méry \& al Tikriti W.Y. 2010 - Life and death in an Early Bronze Age community from Hili, Al Ain, UAE. In Weeks L. (Ed.), Death \& burial in Arabia and beyond, multidisciplinary perspectives, Oxford, BAR International Series 2107: 45-53.

Méry S. 2000 - Les céramiques d'Oman et l'Asie moyenne: une archéologie des échanges à l'Âge du Bronze. Paris, Éditions du CNRS, 314 p.

Méry S. 2010 - Results, limits and potential: burial practices and early Bronze Age societies in the Oman peninsula. In Weeks L.R. (Ed.) Death and burial in Arabia and beyond: multidisciplinary perspectives. Oxford, Archaeopress: 33-44.

Méry S. \& Blackman M.J. 2005 - Socio-economical patterns of a ceramic container : the Harappan black slipped jar. In Jarrige C. \& Lefèvre V. (Ed.), South Asian Archaeology 2001. Proceedings of the sixteenth international conference of the Association of South Asian Archaeologists. Paris, Éditions Recherche sur les Civilisations: 226-235. 
Méry S., Besenval R., Blackman M.J. \& Didier A. 2012 - The origin of the 3rd millennium BC fine grey wares found in eastern Arabia: new evidence from archaeometry. Proceedings of the Seminar for Arabian Studies.

Méry S., Dupont-Delaleuf A. \& Van der Leeuw S. 2010 - Analyse technologique et expérimentations, les techniques de façonnage céramique mettant en jeu la rotation à Hili (Émirats arabes unis) à la fin $\mathrm{du}_{\mathrm{III}}{ }^{\mathrm{e}}$ millénaire (âge du Bronze ancien). In Nouvelles de l'Archéologie $119: 52-58$.

Munoz O. 2004 - Étude anthropologique des tombes Umm an-Nar (Âge du Bronze, Sultanat d'Oman). L'exemple de la tombe 1 de RJ-1. Mémoire de DEA, Université de Paris 1 Panthéon-Sorbonne.

Munoz O., Zazzo A. \& Saliège J.-F. 2013 - Diet and Mobility in a Late Neolithic Population of Coastal Oman Inferred from Radiocarbon Dating and Stable Isotope Analysis. American Journal of Physical Anthropology, doi: 10.1002/ajpa.22434.

Possehl G.L., Thornton C.P. \& Cable C.M. 2010 - A report from the American team for the Ministry of heritage and Culture. Philadelphia, University of Pennsylvania Museum of Archaeology and Anthropology.

Potts D.T. 1986 - Eastern Arabia and the Oman Peninsula during the late fourth and early $3^{\text {rd }}$ millennium B.C. In Finkbeiner U. \& Röllig W. (Ed.), Gamdat nasr, Period or regional style? Beihefte zum Tübinger Atlas des Vorderens Orients, Reihe B $n^{\circ} 62$. Wiesbaden, Dr. Ludwig Reichert: 121-170.

Potts D.T. 1998 - Before the Emirates: an archaeological and historical account of developments in the region c. $5000 \mathrm{BC}$ to $676 \mathrm{AD}$. In Ghareeb E. \& Al Abed I. (Ed.), Perspectives on the United Arab Emirates. London, Trident Press Ltd.: 36-73.

Potts D. T. 2000 - Ancient Magan: The secrets of Tell Abraq. London, Trident Press Ltd., 144 p.

Rouse L.M. \& Weeks L. 2011 - Specialization and social inequality in Bronze Age SE Arabia: analyzing the development of production strategies and economic networks using agent-based modeling. Journal of Archaeological Science 38: 1583-1590.

Santini G. 1987 - Site RH-10 at Qurum and a preliminary analysis of its cemetery: an essay in stratigraphic discontinuity. Proceedings of the Seminar for Arabian Studies 17: 179-198.

Tengberg M. 2003 - Archaeobotany in the Oman Peninsula and the role of Eastern Arabia in the spread of African Crops In Neumann K., Butler A. and Kahlheber S. (Ed.), Food,Fuel and Fields. Progress in African Archaeobotany. Africa Praehistorica. Monographien zur Archäologie und Umwelt Afrikas. Köln, Heinrich-Barth-Institut: 229-37.

Uerpmann M. \& Uerpmann H.-P. 2008 - Animal economy during the Early Bronze Age in southeast Arabia. Archaeozoology of the Near East VIII, TMO 49, Maison de l'Orient méditeranéen: 466-485.

Uerpmann M., Uerpmann H.-P. \& Jasim S.A. 2000 - Stone Age nomadism in SE-Arabia - paleoeconomic considerations on the neolithic site of Al-Buhais 18 in the Emirate of Sharjah, U.A.E. Proceedings of the Seminar for Arabian Studies 30: 229-234.

Weeks L. 2003 - Early Metallurgy of the Persian Gulf: Technology, Trade and the Bronze Age World. Boston, Brill, 249 p.

Weisgerber G. 1981 - Mehr als Kupfer in Oman: Ergebnisse der Expedition 1981. Anschnitt 2-3/32: 62-100. 
Willcox G. 1995 - Some plant impressions from Umm an-Nar Island. In Frifelt K. (Ed.) The Island of Umm an-Nar: vol. 2, the $3^{\text {rd }}$ millennium settlement. Aarhus, Jutland Archaeological Society

Publications 26, Aarhus University Press: 257-259.

\section{ABSTRACTS}

In the peninsula of Oman, the first agricultural oases appeared in the 3rd millennium and developed, bringing profound economic and social change. In the sphere of craft technology, various developments occurred, particularly in the pyro-technologies. These changes favored the emergence of a society that reached its peak during the last third of the 3rd millennium, at the end of the early Bronze Age. Then it was transformed and declined by $2100 \mathrm{BC}$. Approximately a century after, a new type of society/culture emerges, the Wadi Suq Culture, but the subsistence economy of which will continue to base on the agricultural oasis system - except in the (or most of the) coastal sites and the stopping places / hunting places -. The analysis proposed here is centered on the example of the oasis of Hili in the Emirate of Abu Dhabi. Hili is the site on which most specialized studies were realized until now, partially published studies which the author of this article led or in which she took part.

Dans la péninsule d'Oman, le $\mathrm{III}^{\mathrm{e}}$ millénaire voit apparaître et se développer les premières oasis agricoles. Ce processus, complexe et encore mal compris, s'accompagne d'évolutions profondes dans le domaine économique et social. Ainsi, dans la sphère artisanale, on assiste à diverses transformations, en particulier au sein des pyro-technologies. Ces changements favorisent l'émergence d'un nouveau type de société, qui atteindra son apogée au cours du dernier tiers du $\mathrm{III}^{\mathrm{e}}$ millénaire, à la fin de l'âge du Bronze ancien, puis se transforme et décline vers 2100 avant J.C. Un siècle environ plus tard, une société différente par bien des aspects émerge, mais dont l'économie de subsistance continuera de reposer sur le système oasien - sauf dans les habitats côtiers et les haltes/lieux de chasse.

L'analyse proposée ici est centrée sur un exemple, celui de l'oasis de Hili dans l'émirat d'Abou Dhabi, car c'est le site sur lequel le plus d'études spécialisées ont été réalisées jusqu'à présent, des études partiellement publiées que l'auteur de cet article a menées ou auxquelles elle a pris part.

\section{INDEX}

Mots-clés: Néolithique, oasis, spécialisation artisanale, complexification sociétale

Geographical index: Arabie

Keywords: Arabia, Neolithic, Bronze Age, craft specialisation, society complexity

\section{AUTHOR}

\section{SOPHIE MÉRY}

CNRS UMR 7041 Archéologies et Sciences de l'Antiquité

MAE R. Ginouvès

21 allée de l'Université 92023 Nanterre cedex

sophie.mery@mae.u-paris10.fr 